\title{
Humour loss in the Indonesian translation of Harry Potter and the Sorcerer's Stone
}

\author{
Issy Yuliasri* and Pamela Allen \\ English Department, Faculty of Languages and Arts, Universitas Negeri Semarang, Kampus Sekaran Gunungpati \\ Semarang, Central Java, Indonesia \\ School of Humanities (Adjunct Associate Professor), University of Tasmania, Australia
}

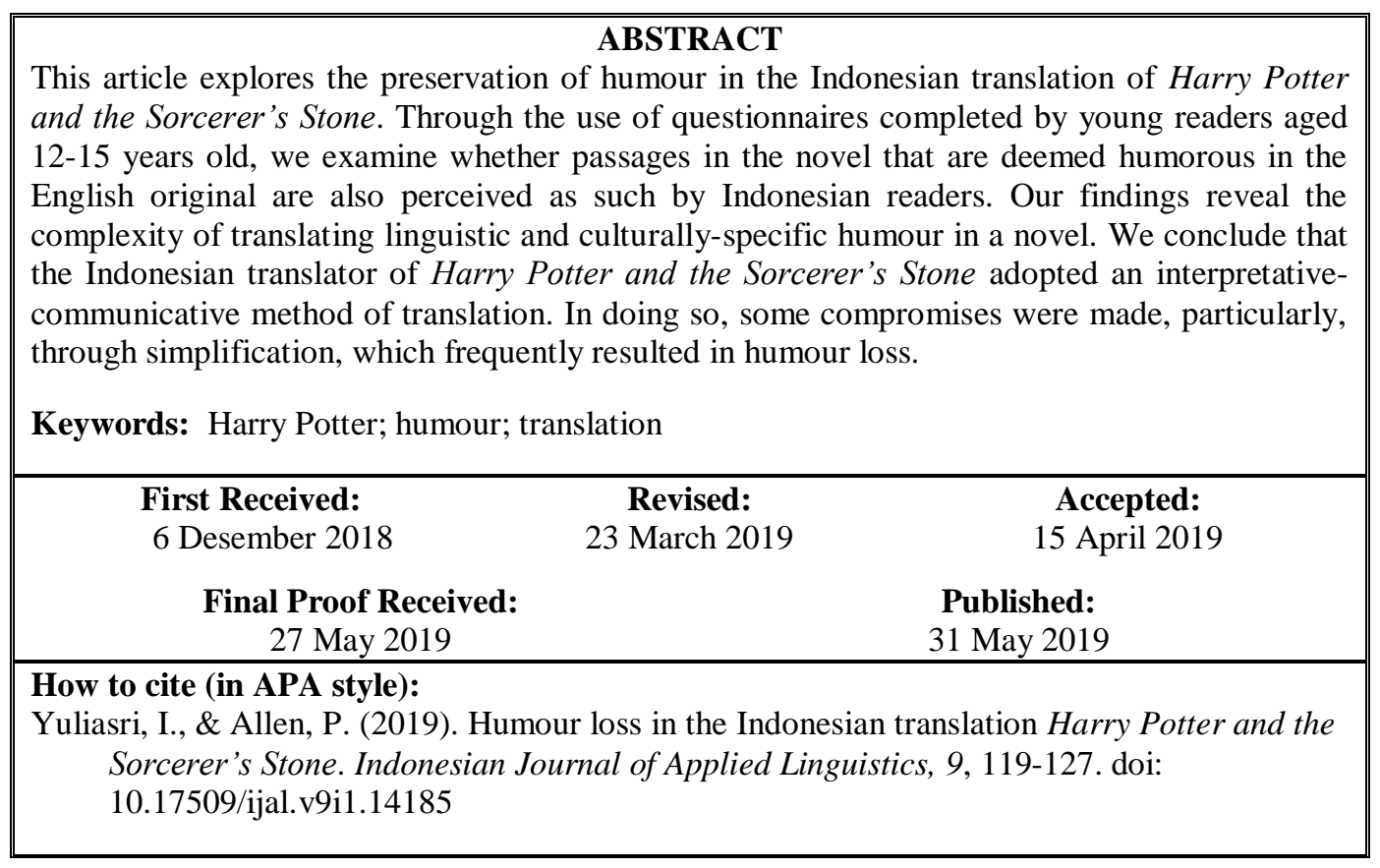

\section{INTRODUCTION}

J.K. Rowling's bestselling Harry Potter series ranks among the most widely read children's books in history. There are 450 million copies in print worldwide, and the series has been translated into 70 languages. In Indonesia, the Harry Potter phenomenon has been as frenetic and widespread as in other countries, with over 200,000 copies of each of the seven Harry Potter titles sold since 2008.

The translator of this series faces a number of challenges. As these novels were written for children, it is our view that the first challenge is to maintain the elements that appeal to younger readers. The second challenge is the large number of culture-specific items in the texts. We refer here to British and/or American culture $^{1}$. Thirdly, the novels are populated by makebelieve characters - wizards, ghosts and poltergeists who live in an equally fictitious world of magic. Hall contextualises Harry Potter within Bakhtin's theory of the carnivalesque in this way: "Harry Potter ... works within the realm of the carnivalesque to illustrate the subversive qualities of laughter in opposition to the official culture the muggle world represents ..." (2011, p.70). In many ways, translating Harry Potter is like translating the carnivalesque. Finally, these novels are humorous and, as Jaskanen observes, when translating humour, the translator "not only has to judge whether the Target Language reader understands the humour in a given text but also to know or guess whether the humour functions as humour in the target culture" (1999, p. 30).

This study seeks to shed some light in an area of literary translation that has received relatively little critical attention: the translation of English language children's books into Indonesian, a language spoken by about 60 million children. In fact, Indonesia has the fourth largest child population in the world. Furthermore, magic and humour are arguably of universal appeal to children. In her essay on why children enjoy fantasy, Pierce describes magic as "that

\footnotetext{
* Corresponding Author

Email: issy.yuliasri@gmail.com
} 
great equalizer between the powerful and the powerless" and fantasy as "a literature of possibilities" (1993, pp. 51-50). In her discussion of the appeal of humour, Mallan reminds us that " $(\mathrm{t})$ he mere mention of many memorable characters ... will spark delighted recognition. Thus, librarians, parents and teachers are often in search of a funny book to read to or buy for children" (1993, p. 6). In this regard, the globalisation of the Harry Potter phenomenon has had a significant impact on the reading choices of children, their parents and their teachers. As Lathey points out, "Never has the role of translators been so essential to publishers and keen readers alike as in the travels of Harry Potter" (2016, p. 133).

The objective of the study is to explore the preservation of humour, much of which depends for its impact on incongruity, the unexpected and wordplay what Delabastita refers to as the "communicatively significant confrontation of two (or more) linguistic structures with more or less similar forms and more or less different meanings" (1996, p. 128) - in the Indonesian translation of Harry Potter and the Sorcerer's Stone. In order to achieve this objective, two approaches are adopted in this paper. We analyse the translation techniques used by the Indonesian translator of HPSS when dealing with the humorous elements of the novel, drawing on Molina and Albir's classification of translation techniques (Molina \& Albir, 2002). Additionally, acknowledging Attardo's caution that the "problems for an essentialist theory of humor are manifold" (Attardo, 1994, p. 3), we analyse the results of questionnaires completed by young readers, in order to ascertain whether passages or events in the novel that are deemed humorous in English are also perceived as such by Indonesian readers. While making no claims for an "essentialist" theory of humour, we aimed to discover whether, within the parameters of different versions - the original and a translation - of a given text, humour can be retained across both linguistic and cultural barriers.

By focusing on the translation of humour, we contribute to an understanding of how humour intended for children can cross linguistic and cultural boundaries, while revealing what may be lost in the process. Such analysis can further the cross-cultural understanding of a linguistic and cultural phenomenon - humour - that forms an important part of effective communication. It can also guide translators in the growing field of English-Indonesian translation to identify English language texts that may appeal to young Indonesian readers because humour therein is deemed transferable across linguistic and cultural barriers.

\section{Translation techniques}

Translation generally refers to the process of transferring written or spoken Source Language (SL) texts to equivalent written or spoken Target Language (TL) texts. While definitions abound, the key purpose of translation is to reproduce various kinds of texts in another language and thus make them available to a wider readership (Ordudari, 2007). Whatever translation ideology the translator adopts - be it Nida's idea of "complete naturalness of expression" (Nida, 1964:159), Venuti's perspective that "a translated text should be the site where a reader gets some sense of a cultural other", or the strategy of "aesthetic discontinuity" (Venuti, 2008, p. 264) - producing an equivalent text presents a plethora of challenges to the translator. This is especially true in the translation of wordplay, which underpins much of the carnivalesque humour of HPSS. Of note here is Tabbert's observation that when it comes to the translation of children's literature, "targetorientedness" is the order of the day" (Tabbert, 2002, p. 305). As we shall see, not all translators and translation scholars agree.

Molina and Albir distinguish between translation strategies and translation techniques. Strategies refer to the "global" approach (which may be conscious or unconscious, verbal or nonverbal) adopted by the translator in the translation task. For example, if there is a problem of comprehension, a translator may use a strategy such as distinguishing main and secondary ideas, or establishing conceptual relationships, or looking for more information. Molina and Albir regard strategies as "a central part of the sub-competencies that make up translation competence" (2002, p. 509).

Once the translator has adopted a strategy, this will materialize through the use of a particular technique. Strategies are thus part of the process; techniques are the linguistic manifestations of the adopted strategies. As Molina and Albir point out, however, some mechanisms may function as both strategies and techniques. Paraphrasing can be used both as a reformulation strategy and as an amplification technique - for example, a cultural item may be paraphrased to be made intelligible to TL readers.

Molina and Albir identify eighteen general translation techniques ${ }^{2}$. The Indonesian translator of HPSS draws on a number of these techniques, as follows:

- Literal translation procedures:

$>$ Borrowing - taking a word directly from another language

$>$ Calque - translating a foreign word or phrase and incorporating it into another language

$>$ Literal translation - word for word translation

- Oblique translation:

$>$ Modulation - a shift in point of view

- Opposing pairs:

$>$ Amplification - using more signifiers to cover syntactic or lexical gaps

$>$ Generalization - translating a term for a more general one (Molina \& Albir, 2002, pp. 509-511)

As he focuses in particular on the translation of children's literature, we also found Tabbert's analysis of 
ways in which a text for children may be "manipulated in translation" useful. He identifies these as

- affiliation to successful models in the target system

- disrespect for the text's integrality (the frequent case of abridgements)

- reduction of complexity (e.g. by eliminating irony)

- ideological adaptation

- adaptation to stylistic norms (Tabbert, 2002, p. 315)

There is a range of diverse, sometimes conflicting, views on translating for children. Some of these views derive from cultural norms and expectations whereby, as Rudvin points out, the target language's literary and cultural norms take priority over "faithfulness" (1994, p. 207). Those norms may vary considerably from one culture to another. In some cultures, there are standards as to what is suitable content for children's books, which circumscribes the work of the translator. As O'Sullivan observes:

the paradox at the heart of the translation of children's literature: it is commonly held that books are translated in order to enrich the children's literature of the target language and to introduce children to foreign cultures, yet at the same time that foreign element itself is often eradicated from translations which are heavily adapted to their target culture $(2005$, p. 64$)$

Elsewhere, O'Sullivan refers to the challenges posed by the fact that children's literature "simultaneously belong(s) to the literary and the pedagogical systems", meaning that literature written for children "passes through social and educational filters not normally activated when literature for adults by adults is translated" (O'Sullivan, 2002, p. 39). Tabbert (2002, p. 203) similarly describes children's literature as being "a traditional domain of teachers and librarians". In the Indonesian context, our research revealed that the big publishers - including the publisher of HPSS - develop guidelines for translators to ensure that cultural norms are adhered to and taboos are not violated. Yuliasri's study of the Indonesian translation of Donald Duck comics also reveals how the translators were expected to manipulate the text in order for it to be acceptable to readers and parents (Yuliasri, 2017).

Translators such as Gote Klingberg, who adopt a prescriptive approach toward translation, guard against altering the integrity of the original work. Klingberg eschews strategies such as "modernization", "purification" and "abridgements" (Klingberg, 1986). His view is in contrast to that of Riitta Oittinen, who maintains that it is more important to be loyal to the target language readers than faithful to the source text (Oittinen, 1993, p. 34). The perils of demanding rigid adherence to the source text are also discussed by Reiss, who identifies three factors that often lead to deviations from the source text: children's imperfect linguistic competence, the avoidance of breaking taboos and the limited world knowledge of young readers (Reiss 1982; cited in Tabbert, 2002, p. 314). For the purposes of this study, we hypothesised that in the case of Harry Potter and the Sorcerer's Stone, a strict observance to the kind of translation equivalence demanded by Klingberg would result in significant humour loss, and in particular that the translator would need to draw on the kinds of translation methods proposed by Delabastita (1994) in order to achieve the effect of the word play and puns in the source text.

\section{Magic and humour}

Sharon Black suggests that "the worldwide, multi-age appeal of Harry Potter may lie in the way these stories of magic meet the needs of readers to find meaning in today's unmagical contexts" (Black, 2003, p. 237). In the Harry Potter stories, young readers are introduced to a world where the very ordinary environment of a school is redefined as a place where wondrous, scary, unimaginable events happen on a daily basis - no less because the curriculum is centred on wizardry. Nothing is the same as in a regular "muggle" school: food, games, clothing - all are imbued with an exciting topsyturviness, making anything seem possible. Because magic depends for much of its impact on incongruity an owl delivering the mail, a train with disappearing carriages, paintings that can move - many magical scenes are also humorous because, as described below, humour often depends on incongruity, on a depiction of the unexpected. In his discussion of the theories of humour, Raskin (1985, pp. 31-32) identifies "inappropriateness, paradox [and] dissimilarity" as characteristics of incongruity, adding that laughter arises from two incongruent components somehow being "brought together, synthesized, made similar."

Understanding humour has given rise to a large body of scholarly work, with scholars identifying various categories of humour, based on different theoretical underpinnings. Schmitz (2002) maintains that all humour falls into one of three categories: realitybased, word-based or culture-based, while Berger categorizes humour into four general categories: language, logic, identity and action. In the category of language, humour is verbal, in logic it is ideational, in identity it is existential, and in action it is physical or non-verbal (Berger, 1993, pp. 17-18). As Berger points out, categories are useful, but in order to analyse humour, we need to drill deeper and identify specific techniques through which it realises itself. Berger further identifies a number of techniques at work in each of the categories ${ }^{3}$. Language humour includes techniques such as bombast, ridicule, insults, wordplay and puns. Logic humour covers techniques like absurdity, coincidence and ignorance. Identity humour involves caricature, eccentricity and the grotesque, and action humour uses slapstick, speed and time. By themselves many of these techniques do not necessarily produce humour; they must complement each other to generate humour. It is Berger's categories and techniques of humour that we draw upon in this paper. We found his multi-layered categorization of humour to 
be particularly useful. We also use Incongruity Theory, a widely accepted theory of humour that states that humour is created out of a conflict between what is expected and what actually happens. It is a theory whose origins go back as far as Aristotle, who defined humour as "something bad", which was interpreted as "something unbefitting, out of place." Kant (1790, p. 177 quoted in Attardo, 1994) defined laughter as "an affection arising from sudden transformation of a strained expectation into nothing", and Schopenhauer explicitly mentions incongruity as a cause of laughter (Raskin, 1985, p. 31). Incongruity Theory assumes that the cognitive capacity to note and understand incongruous events is necessary in order to experience laughter or mirth. People laugh at things that are unexpected or surprising; it is the violation of an expected pattern that provokes humour in the mind of the receiver. Absurdity, nonsense and surprise are vital themes in humour covered by this theory. Berger adds that incongruity covers many meanings: "inconsistent, not harmonious, lacking propriety and not conforming" (1993, p. 3). Within the research on incongruity in humour there has emerged a debate between those who believe that incongruity alone is enough to produce humour and those who maintain that incongruity in itself is not enough, that one has to 'resolve' the incongruity in order to find it funny (Forabosco, 1992). Our view, concurring with Attardo (1994, p. 144) is that a humorous text will have "an element of incongruity and an element of resolution" and that the resolution can be playful rather than realistic or plausible. This is the case in the Harry Potter stories. Furthermore, as mentioned above, magic - unexpected and unaccountable things happening - also relies on incongruity for effect.

\section{Translating humour}

Jaskanen (1999) poses the question of whether translating humour is fundamentally any different from any other form of translation, given that successful translation involves recreating in the TL text those features of the SL text that are relevant for the text to function for a certain purpose. In response, she points out that, arguably, the translator has less latitude with a humorous text, because the translation should be able to function for the TL audience in a maximally similar way as the original text did for the SL audience, "even if this were achieved by substantially altering it". As Munday (2009, p. 195) points out, the translation of humour activates a conflict with two key tenets of translation theory, namely equivalence and translatability. By its very nature, humour "tends to break rules by deliberately exploiting areas of linguistic and semantic duplicity." In his study of puns, for example, Delabastita (1991, p. 146) reminds us that "theoretical as well as critical discussions of this problem usually revolve round the question of whether wordplay is 'translatable' at all." Ideally, as Levine suggests:

the translator of puns, a tinkerer with a musical ear, makes use of her language and its possible association with the language of the source pun and, as Pound advised, selects the living part." If a translator does not recognize, or fails to understand, a joke, a pun, or ironic intent in the SL text, the appeal of the translation can be considerably diminished (1991, p. 15).

As Low (2011, p. 59) bluntly puts it, "if a joke is not translated as a joke, the translation is bad". Low (2011, p. 67) lists six tools for tackling the translation of puns:

(1) replicating the SL pun, when that is possible;

(2) creating a new pun connected verbally with the SL, achieving a kind of dynamic equivalence;

(3) using a different humorous device, particularly where the humour is more important than the meaning;

(4) using compensation in place, to ensure there is wordplay somewhere near the pun;

(5) giving an expanded translation, explaining the pun though sacrificing the fun;

(6) ignoring the pun, rendering only one meaning of the ambiguous phrase, and omitting the wordplay.

The translation of humour is challenging because of the close links between humour and identity and between humour and culture (Maher, 2008, p. 141). Jaskanen observes that the balancing act required to negotiate SL restrictions and TL demands is akin to an exercise in tightrope walking (Jaskanen, 1999, p. 31). As a result, the immediacy of effect can easily be lost. One might argue, for example, that using tools 4,5 or 6 from Low's list above will result in humour loss. In fact, Low himself pleads, "if you can't have the first option, don't immediately fall back on the sixth!" (2011, p. 67). The original humour may include a concept or concepts that are completely unknown within the target culture; it may relate to religious beliefs, a social custom or a type of food. When losses occur, if the translator is to retain the humour, then compensation is needed. "Loss", as Koponen puts it, "does not have to mean that a part of the text has been completely lost, but rather that some aspect that was present in the source text is not there in the target text, e.g. a double meaning, a connotation" (2004, p. 48).

\section{METHOD}

Using Berger's categories of humour, the researchers identified in HPSS examples of what have been deemed as humorous utterances. We then asked a test group of English-speaking readers of HPSS, aged between 12 and 15 , to identify whether they considered those utterances to be humorous or not. This revealed that, using Berger's classification, the types of humour that this cohort of children found humorous were:

- wordplay and puns (relying on nonsense rhymes rather than playing with meaning)

- insults and ridicule

- grotesque

- slapstick 
This concurs with findings reported by Mallan, who includes ridicule, wordplay, grossness and slapstick in a list of things that children belonging to this age group find funny (Mallan, 1993, p. 7).

Additionally, many children identified humour as well as magic in episodes of incongruity in the novel, confirming Ross's assertion that humour is created out of a conflict between what is expected and what actually occurs.

Focusing on the five techniques of insults, wordplay, grotesque, slapstick and incongruity, we then distributed a rating sheet to 25 Indonesian-speaking school students, also aged between 12 and 15, in Semarang, Indonesia ${ }^{4}$. The rating sheet contained the utterances regarded as most humorous by the Englishspeaking readers. Like the English-speaking readers, the Indonesian readers were asked to allocate a score of 3, 2 or 1 to each utterance: 3 indicating that the utterance is funny, 2 indicating that the utterance is not very funny, and 1 indicating that the utterance is not funny at all.

All readers - English-speaking and Indonesianspeaking - were also given a questionnaire consisting of ten open-ended questions. The questions were intended to elicit the respondents' general impression of the novel, its readability, their opinion of the content of the novel (whether it contained humour) and their opinion of the insults contained in the novel, which, in the original text, often overlap with humour. An example of such an insult is $\mathbf{X}$ telling $\mathbf{Y}$ "The poor toilet's never had anything as horrible as your head down it - it might be sick" (Rowling, 2003, p. 37). The students were also asked what aspects of the novel stimulated their imagination.

The Indonesian readers' responses to the translated humorous utterances on the rating sheet were analysed to see if they accorded with the responses of the English-speaking readers. All respondents' answers to the 10 open-ended questions were also analysed.

Our analysis of the responses by Indonesian readers was informed by the consideration that ideas of what is humorous can be influenced by cultural factors. In the Indonesian context, while little extensive research has been done in this area, we found the work of Rustono useful. Drawing on research done by Soedjatmiko on American and Indonesian humour, Rustono (1998, p. 53) suggests that the key difference between American and Indonesian humour lies in a number of different sociocultural factors. For example, the sharp vertical relationships between parents and children, between superior and subordinate, labourer and employer, government and people do not permit Indonesian humour to be presented openly and aggressively. American humour tends to be more open and aggressive as the targets of the humour are familiar with such openness and can easily distract or turn back the humour. Many Asian cultures, including Indonesia, also tend to be introverted about sex so that humour about sex in Indonesia is presented implicitly. Ethnic-related humour is acceptable as long as the target is a group or community (not personal) and is done in irony.
Analysis of the translation techniques was carried out using Molina and Albir's classification. The effect/results of the choice of translation techniques on the rendering of meaning or retention of tone were further analysed. Conclusions were then drawn concerning gains and losses in humour in the translation compared to the original text.

\section{FINDING AND DISCUSSION}

In the discussion below, using the techniques identified by Berger, we classify examples of utterances in HPSS that English-speaking children found humorous. We then identify the techniques used by the Indonesian translator to translate those examples. Guided by Low's view that "what we should and can do is translate humour well enough for it to be recognisable as humour and to have some chance of amusing people", (Low, 2011, p. 60) we judge the extent to which our Indonesian readers have picked up on the intended humour.

\section{Wordplay}

Children are interested in the way language works: They take pleasure in "sound for its own sake and in the absurd; they soon learn that by manipulating language they can appear to make almost anything happen" (Lathey, 2016, p. 107). The nonsense rhymes and imagery of Dr Seuss, for example, have particular appeal for younger readers. When translating such nonsense rhymes, Newmark reminds us that "the soundeffect is more important than the sense" (1988, p. 42). This is because, as Stewart points out, nonsense functions by "bringing attention to form, to method, to the ways in which experience is organized rather than to the 'content' of the organization" (1980, p. 147). Lathey points out, however, that even in nonsense poems like Lewis Carroll's "Jabberwocky" and the limericks of Edward Lear, there may indeed be a semantic level. She argues that such works, along with parodies of wellknown verse, are translatable "as long as translators keep children's developmental fascination with the potential of language in mind" (Lathey, 2016, p. 107).

HPSS Example 1

Source Text (ST): Harry often said that Dudley looked like a pig in a wig.

Target Text (TT): Harry sering mengatakan Dudley seperti babi pakai wig

Back Translation (BT): Harry often said Dudley was like a pig wearing wig.

While the reference to a 'pig in a wig' is to Thomas Hood's 1860 poem 'Precocious Piggy', most juvenile readers of HPSS would be unfamiliar with that ditty. Most English-speaking readers would respond to two categories of humour in this verbal insult. In the language category, there is a kind of infantilism in the rhyming of 'pig' and 'wig', and in the incongruity of two words that don't normally belong together. The image is thus also absurd, falling into the category of logic, which was discussed by Berger as dealing with 
“our sense of possibility and probability" (Berger, 1993, p. 19).

Literal translation occurs when there is "an exact structural, lexical, even morphological equivalence between two languages" (Molina \& Albir, 2002, p. 499). The literal translation technique used in the above example is to translate the English words directly into Indonesian. In opting for a literal translation, rather than trying to find an alternative nonsense rhyme in Indonesian that preserves the form but not the meaning, the translator has eliminated the humour in the wordplay of 'pig' and 'wig'. The Indonesian translation too of course lacks any resonance with any existing nonsense poem. However, as indicated in the fact that almost $70 \%$ of the Indonesian readers rated the utterance as funny, the incongruity of the image was clearly transferred. For Indonesian readers, then, the humour lays exclusively in the semantic impact, not in the assonance. It is worth noting here, however, that references to pigs are often avoided in writing for children in Indonesia, in deference to the predominantly Muslim population. The insult in Indonesian is thus somewhat more culturally sensitive than it is in English.

HPPS Example 2

ST: $[\ldots]$ her sister and her good-for-nothing husband were as unDursleyish as it was possible to be.

TT: [...] adiknya dan suaminya yang tidak berguna itu tidak layak sama sekali menjadi kerabat keluarga Dursley.

BT: $[\ldots]$ her sister and her useless husband were not at all worthy of inclusion in the Dursley family.

Here, the wordplay relies on a kind of implicit contract between the author and the reader, whereby the reader knows what the Dursley family are like (boringly normal), thus giving the author licence to create an adjective from a proper noun. The humour is compounded by the irony that Mrs. Dursley is actually proud to be a Dursley.

The translator, opting for the techniques of generalisation and amplification, has explained the sentiments behind the sentence, describing Mrs. Dursley's brother-in-law as "useless" rather than "goodfor-nothing". In English, while the intent is similar, the term "good-for-nothing" has a more scornful tone than simply "useless". This level of scorn has not been retained in the Indonesian, although the translator could have chosen to use the phrase tak ada gunanya, which corresponds in tone and intent to "good-for-nothing". The translator also expands "unDursleyish" as "unworthy of being a member of the family". The meaning is thus retained, but the humour is lost, as indicated by the responses of the Indonesian readers, of whom only one found the utterance funny. Humour loss is also compounded by the fact that the target readers do not have access to the culture-specific information that the Dursleys are boringly normal.

\section{Puns}

Puns exploit the ambiguities of words or phrases. They present significant challenges for translators because they draw on the specific features of a particular language (Low, 2011, p. 59). The following example is one of a number of clever puns on names that Rowling uses in the novel:

HPSS Example 1

ST: "Welcome," said Hagrid, "to Diagon Alley."

TT: "Selamat datang", kata Hagrid, "di Diagon Alley."

BT: "Welcome," said Hagrid, "to Diagon Alley."

Here the humour is totally reliant on wordplay. The name of the alley is a quirky play on 'alley' and the adverbial ending '-ally', with the name 'Diagon Alley' sounding like the adverb 'diagonally'. Using the borrowing technique, the translator chose to simply retain the English words; as a result, neither the meaning nor the pun is captured.

\section{Insults}

Insults fall on what might be called the negative side of humour, the aggressive side: "masked aggression and hostility" (Berger, 1993, p. 40). An early proponent of insult as humour was Thomas Hobbes (1588-1679), whose Superiority Theory focused on the idea that "laughter arises from a sense of superiority of the laugher towards some object" (Attardo, 1994, p. 47). Spinoza put it more bluntly: "A man hates what he laughs at" (Morreall, 2008, p. 220). Berger (1993) suggests that insults on their own are not necessarily funny but that, combined with comparisons and exaggeration, the impact can be amusing. According to Beckman (1984, cited in Mallan, 1993), the most common type of humour amongst children relates to derogatory remarks and name-calling. The insults in HPSS deemed to be funny by both English and Indonesian readers were unambiguous, no-nonsense schoolboy putdowns like the following:

HPPS Example 1

ST: "Oy, pea-brain!"

TT: "Oi, otak kacang polong!"

BT: "Oy, pea-brain!"

HPPS Example 2

ST: "If brains were gold, you'd be poorer than Weasley."

TT: "Kalau otak terbuat dari emas, kau lebih miskin daripada si Weasley."

BT: "If brains were gold, you'd be poorer than Weasley."

In both examples, the translator used literal translation; both utterances were deemed funny by both English and Indonesian readers. In the case of pea-brain the translator could have opted for the common Indonesian expression otak udang ("prawn brain"), which would have created an established equivalence. Her decision to use the literal translation has not resulted in humour loss - suggesting that name-calling crosses cultures and, being easy to translate literally, also crosses the linguistic divide.

\section{Ridicule}

As well as the name-calling and schoolboy insults identified above, there is also a lot of inherent "genial 
ridicule", to use Berger's phrase (1993, p. 48) in HPSS, as exemplified in the following excerpt:

HPSS Example

ST: Mr. Dursley hummed as he picked out his most boring tie for work, and Mrs. Dursley gossiped away happily as she wrestled a screaming Dudley into his high chair.

TT: Mr Dursley bersenandung ketika dia mengambil dasinya yang sangat membosankan untuk dipakainya bekerja, dan Mrs Dursley bergosip riang seraya berkutat dengan Dudley yang menjerit-jerit dan mendudukkan anak itu di kursinya yang tinggi.

BT: Mr. Dursley was humming when he took his very boring tie to wear to work, and Mrs. Dursley was gossiping cheerfully while she was busy with Dudley, who was screaming, and sat him on his high chair.

The humour in the original text derives from the incongruous juxtaposition of five markedly different actions within the one snapshot scene - picking out a tie, humming, gossiping, wrestling, screaming. One would not expect a mother to be happily gossiping as her child is misbehaving in this way.

Whether intentional or not, the translator has used the strategy of generalisation to translate this sentence, which lessens the humorous impact in a number of ways. In the original, Mr. Dursley consciously picks out his most boring tie, enhancing the sense of how boring he is. In the Indonesian, he simply "takes a very boring tie", which makes it seem accidental somehow, as if the tie just happened to be lying there and happened to be boring. Generalisation also occurs in the use of berkutat, meaning 'busying oneself with', instead of the much more aggressive 'wrestle'. The Indonesian translator may not have picked up on the subtle ridicule and the jarring juxtaposition of actions in this description of the Dursley family's morning routine. While these attributes could have been conveyed in the translation, the choice of verbs has reduced the description to a mundane, matter-of-fact sentence.

\section{Grotesque}

Mallan (1993, p. 7) observes that "by late primary school and early high school, grossness is a popular channel for humour". She attributes this to the desire at that age to break away from childhood and adult codes of what is deemed acceptable behaviour. In his discussion of the grotesque in Roald Dahl's books for children, West draws on the work of child psychologist Paul E. McGhee, who examines the psychological dynamics associated with toilet training in order to understand why children laugh at the grotesque. McGhee observes that "the idea that certain things or actions are disgusting is usually absorbed while children are experiencing bladder and bowel training." Parents tend to become upset when things occur at the wrong place or the wrong time and in turn such parental responses often spark feelings of anxiety in children. One way that they deal with their anxiety is through humour (West, 1990). Our readers were given the opportunity in the open-ended questions to nominate parts of HPSS that they found humorous. The most commonly cited passages were insults and anything to do with toilets, pigs, rats or earwax.

HPSS Example

ST: Then he choked and said, "Alas! Ear wax!"

TT: Kemudian dia tersendak dan berkata, "Ya ampun! Rasa kotoran telinga!"

BT: Then he choked and said "Alas! It's ear wax flavoured!'

As with the translation of the insults in the above examples, the use of literal translation here (albeit with the amplification that it was ear wax flavoured, not actual ear wax) preserved the meaning, the humour and the sense of disgust of the original.

Young readers were also amused by the Weasley twins' mother begging them not to blow up any more toilets, and by their promise to send their sister a Hogwarts toilet seat. Such humour apparently has a long history: Mallan reports that children's enjoyment of rhymes and comments about underpants and toilets is not a recent phenomenon; rather, children have long enjoyed "mild scatological humour". Iona and Peter Opie have traced the origins of children's rhymes about underpants back to the nineteenth century (Mallan, 1993).

\section{Slapstick}

An infantile type of visual humour, slapstick is physical, involving situations like slipping on a banana skin, or getting a pie in the face. It is often a kind of "objectified insult" (Berger, 1993, p. 51). A very popular utterance among both English and Indonesian readers combines the humour of the putdown, the "grossness" of bodily functions and the visual impact of a slapstick scene:

HPPS Example

ST: "The poor toilet's never had anything as horrible as your head down it - it might be sick."

TT: "Kasihan toilet, belum pernah kemasukan benda lain yang lebih mengerikan daripada kepalamu jangan-jangan toilet itu sekarang sedang mual.'

BT: "Poor toilet, it has never been entered by anything more horrible than your head - I hope it's not feeling sick now."

The humour in this example is quite complex. It expresses the insult that Dudley is more repellent than all the other things that normally go down a toilet. This is overlaid by the incongruities of personification attributing human feelings like nausea to a toilet - and of suggesting that it would be the toilet, rather than the person whose head is in the toilet, who might be feeling sick.

The Indonesian translator employed modulation in the translation of this sentence. Instead of saying "anything as horrible as your head", the Indonesian version reads "anything more horrible than your head". The humorous impact is retained, however, and this image was a big hit with the Indonesian readers. Even if the complexity of this particular excerpt and the incongruities inherent in it were lost on the readers, if it 
involves someone's head down the toilet then it is funny.

\section{Incongruity}

The slapstick toilet image in the above example also falls into the category of incongruity, a type of humour that children appreciate with increasing sophistication as they grow older. In order to appreciate incongruity, then, a child has to have a sense of what a "normal state of affairs" is. A child's apprehension of incongruity may thus be constrained by their "limited world knowledge" (Reiss, 1982 cited in Tabbert, 2002, p. 314).

\section{HPPS Example}

ST: Hagrid took up two seats and sat knitting what looked like a canary-yellow circus tent.

TT: Hagrid duduk di dua kursi dan merajut sesuatu yang kelihatannya seperti tenda sirkus warna kuning kenari

BT: Hagrid sat on two chairs and knitted something that looked like a canary yellow circus tent.

Relying for its humorous impact on the incongruity of the huge, gruff Hagrid, with his "long, shaggy mane of hair and a wild, tangled beard" (Rowling, 2003, p. 46), engaged in such a dainty occupation as knitting, the image is further enhanced by the incongruity of a circus tent a) being knitted and b) being canary yellow. Incongruity is humorous because it highlights the difference between what we have come to expect and what we see in front of us. As one of the English-language readers put it: "Hagrid is the last person you would think to knit."

The Indonesian translation is literal, but the young readers found no humour in this passage. Many of the Indonesian readers used the term "magical" to describe their overall feeling about HPSS. For those readers, perhaps the image of Hagrid knitting a yellow circus tent is not incongruous in Hogwarts. It is a magical subversion of the normal order of things, rather than a humorous one.

\section{CONCLUSION}

In the discussion above, reference was made to the fact that, by and large, children do not think of the Harry Potter books as being primarily humorous. However, while the primary function of HPSS may not be to amuse with humour, but to transport readers to an imaginary, magical world of wizards and witchcraft, we have demonstrated that humorous and comical allusions are prevalent in the book, covering the four categories identified by Berger - language, logic, identity and action - and employing a number of the techniques he describes. Furthermore, because magic and incongruity often combine with other elements of humour, such as wordplay, insult and slapstick, the readers were in fact able to identify elements of the novel that they found humorous, that made them laugh.

The translator is faced with finding ways to convey a story that is dependent for its impact on both magic and humour - sometimes explicit, sometimes subtle. Munday reminds us that if the function of a text is to amuse, but it poses difficult translation problems, "it is not unusual to find that text either eliminated altogether or else substituted with a completely different text which will be equally entertaining in the TL" (Munday, 2009, p. 196). Our research has shown that, while the Indonesian translator has achieved functional equivalence in the translation of many of those humorous elements, there are some, in particular those dependent on linguistic humours that do not readily translate or have not been translated successfully. With regard to translation loss or gain, we conclude that the Indonesian translator of Harry Potter and the Sorcerer's Stone adopted an interpretative-communicative method of translation. In doing so, some compromises were made, particularly through reduction in complexity (Tabbert, 2002), and without the compensation required to retain the level of humour.

\section{REFERENCES}

Attardo, S. (1994). Linguistic theories of humor. Berlin and New York: Mouton de Gruyter.

Berger, A. A. (1993). An anatomy of humor. New Brunswick, N.J., U.S.A.: Transaction Publishers.

Black, S. (2003). The magic of Harry Potter: Symbols and heroes of fantasy. Children's Literature in Education, 34(3), 237-247. https://doi.org/10.1023/A:1025314919836

Delabastita, D. (1991). A False opposition in translation studies: Theoretical versus/and historical approaches. Target, 3(2), 137-152. https://doi.org/10.1075/target.3.2.02del

Delabastita, D. (1994). Focus on the pun. Target, 6(2), 223-243. https://doi.org/10.1075/target.6.2.07del

Delabastita, D. (1996). Introduction. The Translator, 2(2), 127-139. https://doi.org/10.1080/13556509.1996.10798970

Forabosco, G. (1992). Cognitive aspects of the humor process: The concept of incongruity. HUMOR, 5(1), 45-68.

http://psycnet.apa.org/doi/10.1515/humr.1992.5.12.45

Hall, G. (2011). Exploring English language teaching: Language in action. New York: Routledge. https://doi.org/10.4324/9780203827840

Jaskanen, S. (1999). On the inside track to Loserville, USA: Strategies used in translating humour in two Finnish versions of reality bites. University of Helsinki, Finland. https://doi.org/10.1075/target.6.2.07del

Klingberg, G. (1986). Children's fiction in the hands of the translators. Lund, Sweden: CWK Gleerup.

Koponen, M. (2004). Wordplay in Donald Duck comics and their Finnish Translations. University of Helsinki. Retrieved from http://ethesis.helsinki.fi/julkaisut/hum/engla/pg/ko ponen/wordplay

Lathey, G. (2016). Translating children's literature. 
London \& New York: Routledge.

Levine, S. (1991). The subversive scribe: Translating Latin American fiction. Saint Paul: Graywolf Press.

Low, P. A. (2011). Translating jokes and puns. Perspectives: Studies in Translatology, 19(1), 5970. https://doi.org/10.1080/0907676X.2010.493219

Maher, B. (2008). Identity and humour in translation: The extravagant comic style of Rosa Cappiello's Pase fortunate. In P. Nikolaou \& M.-V. Kyritsi (Eds.), Translating selves: Experience and identity between languages and cultures (pp. 141-153). London: Continuum.

Mallan, K. (1993). Laugh lines: Exploring humour in children's literature. Newtown, Australia: Primary English Teaching Association.

Molina, L., \& Hurtado Albir, A. (2002). Translation techniques revisited: A dynamic and functionalist approach. Meta: Journal Des Traducteurs, 47(4), 498. https://doi.org/10.7202/008033ar

Morreall, J. (2008). Philosophy and religion. In V. Raskin \& W. Ruch (Eds.), The primer of humor research (pp. 211-242). Berlin and New York: Mouton de Gruyter.

Munday, J. (Ed.). (2009). The Routledge companion to translation studies. London \& New York: Routledge.

Newmark, P. (1988). A textbook of translation. New York: Prentice Hall.

Nida, E. A. (1964). Toward a science of translating. Leiden: E.J. Brill.

O’Sullivan, E. (2002). Comparing children's literature. Retrieved August 3, 2015, from http://www.gfljournal.de/2-2002/osullivan.pdf

O'Sullivan, E. (2005). Comparative children's literature. London \& New York: Routledge.

Oittinen, R. (1993). I am me - I am other: On the dialogics of translating for children. University of Tampere. Retrieved from https://books.google.co.id/books?id=642vMQEAC AAJ

Ordudari, M. (2007). Translation procedures, techniques and methods. Retrieved October 23, 2014, from http://www.translationdirectory.com/articles/article 1413.php

Pierce, T. (1993). Fantasy: Why kids read it, why kids need it. School Library Journal, 39, 50-51.

Raskin, V. (1985). Semantic mechanisms of humor. Dordrecht: Reidel.

Rowling, J. K. (Joanne). (2003). Harry Potter and the sorcerer's stone. New York: Scholastic Inc.; trans. by Listiana Srisanti (2008) as Harry Potter dan Batu Bertuah. Jakarta: Gramedia.

Rudvin, M. (1994). Translation and 'myth': Norwegian children's literature in English.
Perspectives, 2(2), 199-211.

https://doi.org/10.1080/0907676X.1994.9961236

Rustono, R. (1998). Implikatur percakapan sebagai penunjang pengungkapan humor di dalam wacana humor verbal lisan berbahasa Indonesia.

Disertasi. Indonesia University, Indonesia.

Schmitz, J. R. (2002). Humor as a pedagogical tool in foreign language and translation courses. Humor International Journal of Humor Research. https://doi.org/10.1515/humr.2002.007

Stewart, S. (1980). Nonsense: Aspects of intertextuality in folklore and literature. Baltimore: Johns Hopkins University Press.

Tabbert, R. (2002). Approaches to the translation of children's literature. Target, 14(2), 303-351. https://doi.org/10.1075/target.14.2.06tab

Venuti, L. (2008). The translator's invisibility: A history of translation. London and New York: Routledge.

West, M. (1990). The grotesque and the taboo in Roald Dahl's humorous writings for children. Children's Literature Association Quarterly, 15(3), 115-116. https://doi.org/10.1353/chq.0.0822

Yuliasri, I. (2017). Translators' censorship in EnglishIndonesian translation of Donald Duck Comics. Indonesian Journal of Applied Linguistics, 7(1), 105-116. http://dx.doi.org/10.17509/ijal.v7i1.6863

\footnotetext{
${ }^{1}$ The book was released in the United States under the title Harry Potter and the Sorcerer's Stone, because the publishers were concerned that most Americans were not familiar enough with the reference to alchemy inherent in the "Philosopher's Stone". The decision was thus made to choose a title that was more suggestive of magic. Because the Indonesian translator used the American version, Harry Potter and the Sorcerer's Stone, it is this version that we use as Source Text, henceforth referred to as HPSS in this paper.

2 1) adaptation, 2) amplification, 3) borrowing, 4) calque, 5) compensation, 6) description, 7) discursive creation, 8) established equivalence, 9) generalization, 10) linguistic amplification, 11) linguistic compression, 12) literal translation, 13) modulation, 14) particularization, 15) reduction, 16) substitution, 17) transposition and 18) variation

${ }^{3}$ Language: allusion, bombast, definition, exaggeration, facetiousness, insults, infantilism, irony, misunderstanding, over literalness, puns/wordplay, repartee, rhetorical exuberance, ridicule, sarcasm, satire Logic: absurdity, accident, analogy, catalogue, coincidence, disappointment, ignorance, mistakes, repetition, reversal, rigidity, theme/variation

Identity: before/after, burlesque, caricature, eccentricity, embarrassment, exposure, grotesque, imitation, impersonation, mimicry, parody, scale, stereotype, unmasking

Action: chase, slapstick, speed, time

${ }^{4}$ Our decision to use a sample of 25 students was based on general guidelines that in descriptive qualitative research an optimum sample size is 15-30 (Baker and Edwards)
} 